\title{
BIODESULPHURIZATION OF THIOPHENE AS A SULPHUR MODEL COMPOUND IN CRUDE OILS BY Pseudomonas aeruginosa SUPPORTED ON POLYETHYLENE
}

\author{
BIODESULFURYZACJA MODELOWEGO ZWIĄZKU SIARKI \\ W SUROWEJ ROPIE NAFTOWEJ - TIOFENU \\ PRZEZ Pseudomonas aeruginosa NA PODŁOŻU POLIETYLENOWYM
}

\begin{abstract}
A new biodesulphurization method has been considered using Pseudomonas aeruginosa supported on polyethylene (PE) for biodesulphurization (BDS) of thiophene as an aromatic sulphur model compound of crude oils. Also the biodegradation of thiophene has been modified in the presence of potassium hexacyanoferrate(III) as a terminal electron acceptor to approach the maximum biodesulphurization efficiency. The obtaining results according to UV-Spectrophotometry at $240 \mathrm{~nm}, 83.3 \%$ of thiophene at the primary concentration of $50 \mathrm{mg} / \mathrm{dm}^{3}$, $\mathrm{pH}=7$, by $0.5 \mathrm{~g}$ of biocatalyst in $37^{\circ} \mathrm{C}$ after $4 \mathrm{~h}$ of contact time has been removed. The bacterial cells exhibited a greater and faster biodegradation in the presence of potassium hexacyanoferrate(III) and $94.8 \%$ of thiophene has been removed after $3 \mathrm{~h}$ of contact time. Kinetic study predicted chemisorption of thiophene on the surface of the biocatalyst, as it followed the pseudo-second-order rate equation. Morphology and surface functional groups of the biocatalyst have been investigated by SEM and FT-IR, respectively.
\end{abstract}

Keywords: biodesulphurization, Pseudomonas aeruginosa, polyethylene, thiophene, crude oil

\section{Introduction}

The combustion of sulphur-containing fossil fuels has led to the release many types of pollutants into the atmosphere such as sulphur dioxide which is air and water pollutant, thus the reduction of total sulphur content in fossil fuels has received increasing attention with growing environmental protection. The environmental regulations are now put in place to regulate the level of sulphur in different fossil fuels [1-3]. The higher sulphur levels in fossil fuels obtained from aromatic sulphur heterocyclic compounds, these molecules break down and produce environmental hazards $[4,5]$. A lot of effort is now spent on developing novel and efficient hydrogen and non-hydrogen desulphurization technologies $[2,6]$. The

\footnotetext{
${ }^{1}$ Department of Chemical Engineering, College of Engineering, Kermanshah Branch, Islamic Azad University, Kermanshah, Iran, phone +98 9183588590, fax +98 8337243196, email: Amjad-k-2006@iauksh.ac.ir

${ }^{2}$ Department of Chemistry, College of Basic Sciences, Kermanshah Branch, Islamic Azad University, Kermanshah, 6718997551, Iran, phone +98 8337243181, fax +98 8337243196, email: soroorsadeghi@iauksh.ac.ir ${ }^{3}$ Department of Chemical Engineering, College of Engineering, Kermanshah Branch, Islamic Azad University, Kermanshah, Iran, phone +98 9388179853, fax +98 8337243196, email: f.salimi@iauksh.ac.ir

*Corresponding author: soroorsadeghi@iauksh.ac.ir
} 
most widely used technology to remove sulphur from crude operates is hydrodesulphurization (HDS) [7]. In spite the effectiveness of HDS, the operation is a high-energy consumer and cannot completely remove these heterocyclic organosulphur compounds such as thiophene and its derivatives. Thus bio-catalytic desulphurization is now being considered due to some limitations with conventional hydrodesulphurization approach. These procedures that are now been considered for desulphurization of fossil fuels include biocatalytic desulphurization or biodesulphurization (BDS), a biocatalytic process performed by microorganisms that selectively remove sulphur from hydrocarbon fractions, is an interesting alternative and considered an environmentally friendly process because of the mild operative pressure and temperature conditions [2, 4, 8-10]. BDS not require the application of additional technologies to remove toxic molecules generated during the reaction [11-16]. Biodegradation is more effective, powerful and economical provident than physical and chemical ways, also the simplicity and lower cost of BDS make this process much more interesting [17-19]. Thiophenic compounds have been used as aromatic sulphur model for BDS process and transforming recalcitrant organosulphur compounds found in a variety of fossil fuels [20-22].

Several bacterial strains are able to selectively oxidize the sulphur atom of thiophenic compounds without degrading its carbon skeleton have been isolated [11, 20, 21, 23]. Also the role of sulphite oxidoreductase and sulphite reductase in biodesulphurization of thiophenic compounds by bacterial strains has been investigated [24]. The biodesulphurization process consists of a two-phase system in which the whole cell as a biocatalyst in the aqueous phase interacts with the oil phase [25].

Biomodification of chemical supports using cells immobilization via adsorption increases the interaction between reactants present in two-phase systems [26-28]. These materials must be inert to biological attack, insoluble in the growth media and non-toxic to microbial cells, hence polymeric supports are proper choices, sorption capacity, chemical resistance and mechanical strength of polymer support and solubility parameter is the main factor in the selection of a polymer support [29-31]. However, few studies have evaluated the influence of inorganic supports on the BDS activity and using polymers as the support for bacterial strain for BDS never have been observed [32, 33]. Pseudomonas species are able to grow with cyanide as the sole nitrogen source and several enzyme activities of these bacterial strains were significantly higher than those observed with other nitrogen sources [34]. Also the bacterial cells exhibited a greater extent and rate of biodegradation in the presence of ferricyanide as the terminal electron acceptor compared to the individual cells [35].The purpose of this study is to investigate biodesulphurization ability of $P$. aeruginosa supported on polyethylene in the presence of potassium hexacyanoferrate(III) in thiophene biodegradation as an aromatic sulphur model compound of crude oil.

\section{Materials and methods}

\section{Chemicals}

Thiophene, hexane, polyethylene granules, potassium hexacyanoferrate(III), di potassium hydrogen phosphate were purchased from Merck (Germany). All media and solutions were prepared with deionized water. The culture medium was Tryptone soya broth: $17 \mathrm{~g}$ peptone from casein, $3 \mathrm{~g}$ peptone from soymeal, $2.5 \mathrm{~g} \mathrm{D}(+)$ Glucose monohydrate, $5 \mathrm{~g}$ sodium chloride, $2.5 \mathrm{~g}$ dipotassium hydrogen phosphate in $1000 \mathrm{~cm}^{3}$ of deionized water $(\mathrm{pH}=7)$. 


\section{Microorganism and cell immobilization}

Pseudomonas aeruginosa strain was isolated from wound. Quality control strain for AFNOR and ISO norms was purchased from Persian Type Culture Collection (PTCC-1310). The culture medium was sterilized by autoclaving at $121^{\circ} \mathrm{C}$ for 15 minutes. For cultivation of the strain, $250 \mathrm{~cm}^{3}$ flasks containing $50 \mathrm{~cm}^{3}$ of medium supplemented with $0.25 \mathrm{mM}$ thiophene were incubated at $37^{\circ} \mathrm{C}$ with shaking at $200 \mathrm{rpm}$ for $96 \mathrm{~h}$ (IKA KS130 basic). During the course of cultivation, aliquots of the culture were collected for measurements of cell growth by turbidimetric assay at $600 \mathrm{~nm}$ [27]. The resting cells were prepared by harvesting the cells in mid-logarithmic phase $\left(\mathrm{OD}_{600}=1\right)$ by centrifugation at $4000 \mathrm{~g}$ for $30 \mathrm{~min}$ (Froilabo SW14) and washing twice with $0.1 \mathrm{M}$ potassium phosphate buffer [36].

Before immobilization process, polyethylene granules was autoclaved at $120^{\circ} \mathrm{C}$ for 20 min. Resting cells were suspended in $50 \mathrm{~cm}^{3}$ of potassium phosphate buffer $(0.1 \mathrm{M}$, $\mathrm{pH}=7$ ). For the immobilization process the bacteria cell numbers were adjusted by measuring the turbidity at $600 \mathrm{~nm}\left(\mathrm{OD}_{600}\right)$ with a UV-Visible spectrophotometer (Spectro scan $60 \mathrm{DV})$ [27]. Suspended bacterial cells were contacted with polymer support (1:1) at $37^{\circ} \mathrm{C}$ in rotary shaker at $200 \mathrm{rpm}$ during $72 \mathrm{~h} \mathrm{[37].} \mathrm{The} \mathrm{number} \mathrm{of} \mathrm{immobilized} \mathrm{cells} \mathrm{was}$ measured by loses of turbidity of solution at $600 \mathrm{~nm}\left(\mathrm{OD}_{600}\right)$. The biocatalysts were designated as bacterial cell/solid systems, where the bacterial cells correspond to $P$. aeruginosa and the solid corresponds to the polymeric supports [38]. For morphological studies on biocatalyst scanning electron microscope (MIRA TESCAN SEM) images were prepared before and after cell immobilization process. Also for considering surface functional groups of the biocatalyst and interaction between the adsorbed cells and polymeric support, FT-IR spectra from 400 to $4000 \mathrm{~cm}^{-1}$ was carried out on Bruker-ALPHA instrument.

\section{Thiophene BDS by immobilized cells}

For two-phase BDS studies, resuspension was performed using a 1:1 volume ratio of potassium phosphate buffer and n-hexane [36]. Optimum condition for BDS studies was carried out using different amounts of biocatalyst $(0.1-0.5 \mathrm{~g})$ that was placed in a $25 \mathrm{~cm}^{3}$ flask containing $10 \mathrm{~cm}^{3}$ of thiophene (from 50 to $200 \mathrm{mg} / \mathrm{dm}^{3}$ ) as crude oil sulphur model compound. Also BDS activity has been studied in the presence of potassium hexacyanoferrate(III) $(0.5 \mathrm{M})$ as electron acceptor. The reaction was carried out at $37^{\circ} \mathrm{C}$ in a rotary shaker at $200 \mathrm{rpm}$ from 1 to $4 \mathrm{~h}$ of contact time. The hydrocarbon phase was separated from the aqueous phase by centrifugation at $12000 \mathrm{~g}$. The remained thiophene amount after BDS was determined by UV-spectrophotometry at $240 \mathrm{~nm}$ [37].

\section{Results and discussions}

\section{Cells immobilization}

The surface morphology and P. aeruginosa adsorption on PE was detected by scanning electron microscope (Fig. 1). The SEM image indicating that the polymer support surface was coated by the microorganisms during the immobilization process. The SEM image also suggests some regular layered shape for supported bacteria. The SEM images showed that bacterial cells have maintained their morphology on polymeric support after 60 days from immobilization process while free whole cells were all destructed after this time (Fig. 1c), 
the images also suggests some regular layered shape for supported bacteria in the presence of potassium hexacyanoferrate(III) which have maintained their rods morphology in much more regular form (Fig. 1b). In comparison with Figure 1a, presence of potassium hexacyanoferrate(III) as a nitrogen source for bacteria, yields to such regular layered morphology with more active surface area which can be seen that more bacterial cells have maintained their morphology after 60 days on polymer.

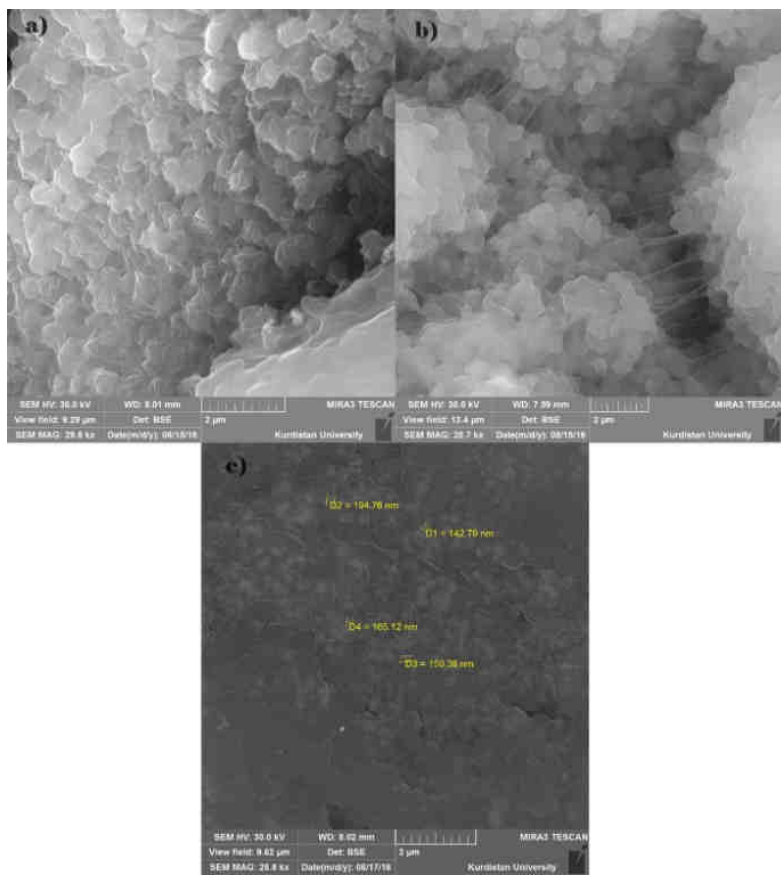

Fig. 1. SEM image of: a) $P$. aeruginosa supported on PE after 60 days from immobilization process, b) SEM image of $P$. aeruginosa supported on PE after 60 days from immobilization process in the presence of potassium hexacyanoferrate as nitrogen source and electron acceptor agent (modified biocatalyst), c) free cells of $P$. aeruginosa after 60 days from cultivation process

Immobilization process has been considered by FT-IR spectra (Fig. 2).
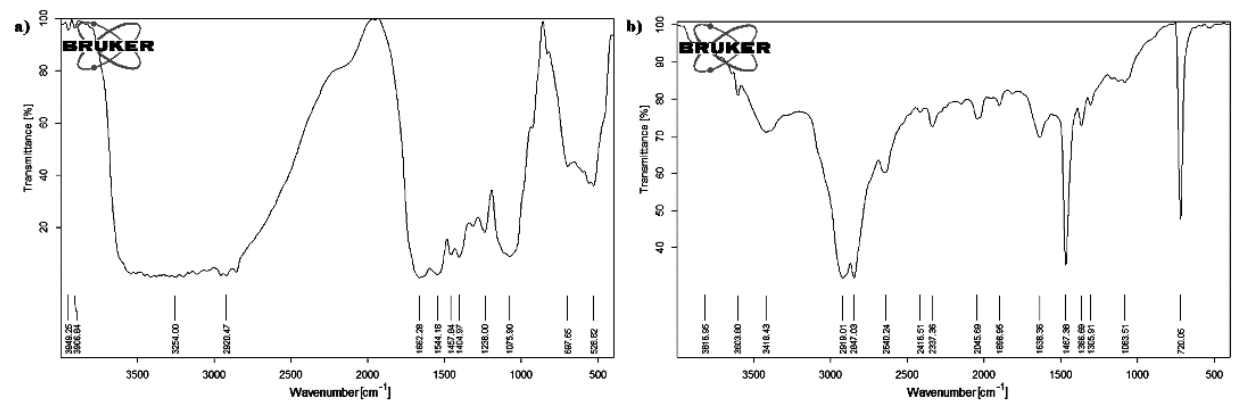

Fig. 2. a) FT-IR spectrum of $P$. aeruginosa, b) FT-IR spectrum of immobilized bacterial cells on PE in the presence of potassium hexacyanoferrate(III) 
Figure 2a shows the FT-IR spectrum of $P$. aeruginosa, The band at $3254 \mathrm{~cm}^{-1}$ can be attributed to stretching mode of $\mathrm{OH}$ and $\mathrm{NH}$ from amide II, bending mode for $\mathrm{NH}$ in amide II appears at $1544 \mathrm{~cm}^{-1}$, the band at $1662 \mathrm{~cm}^{-1}$ is indicative of the appearance of carbonyl stretching mode in amides from protein structure and the band at $1075 \mathrm{~cm}^{-1}$ attributed to carbonyl stretching mode from polysaccharides. The bands at 2920 and $2800 \mathrm{~cm}^{-1}$ are associated with the stretching of $\mathrm{CH}_{2}$ and $\mathrm{CH}_{3}$ in protein structure and their bending mode appears at $1457 \mathrm{~cm}^{-1}$. The bands at 1404 and $697 \mathrm{~cm}^{-1}$ can be attributed to symmetric stretching mode and bending mode of carboxyl groups, respectively. The band at $1238 \mathrm{~cm}^{-1}$ can be attributed to C-O-C groups from polysaccharides. Figure $2 \mathrm{~b}$ shows the FT-IR spectrum of immobilized bacterial cells on PE. The bands at 3418.43 and $3603.8 \mathrm{~cm}^{-1}$ can be attributed to stretching mode of $\mathrm{OH}$ and $\mathrm{NH}$ from amide(II), the band at $1638.36 \mathrm{~cm}^{-1}$ is indicative of the appearance of carbonyl stretching mode in amides from protein structure. The bands at 2919.01 and $2847.03 \mathrm{~cm}^{-1}$ are associated with the stretching of $\mathrm{CH}_{2}$ and $\mathrm{CH}_{3}$ in protein structure and their bending mode appears at $1467.38 \mathrm{~cm}^{-1}$. The weak bands at 1366.69 and $1305.91 \mathrm{~cm}^{-1}$ can be attributed to stretching mode of C-N groups. Bending mode of C-H from fatty acids appears at $720.05 \mathrm{~cm}^{-1}$ and the weak broad band at $1083.51 \mathrm{~cm}^{-1}$ can be attributed to the stretching mode from carboxylic groups of polysaccharides. Immobilization results according to FT-IR spectra indicate the best interaction between bacterial cells and polymer supports. Immobilization process of bacterial cells on the support is usually explained by electrostatic interactions [38, 39]. The methods for bacterial cells immobilization considered the cells entrapment and cells adsorption [26, 33]. However, the adsorption of cells on polymer support require more complex chemical and biochemical analysis that also consider non-electrostatic interactions and bacterial hydrophobic behaviour [38]. Although the interactive forces are important in the adsorption process of bacteria on solids, other physical and biological factors can also influence this process, such as the size of bacterial cells, ionic strength and the surface structure of the supports [39-41]. Thus, the major level of BDS activity observed in biocatalysts can be explained by high no-electrostatic interaction between the cells and supports [42]. So the access of $\mathrm{P}$. aeruginosa cells to the hydrophobic phase is facilitated, in comparison to whole non-adsorbed cells [38].

\section{Biodesulphurization of thiophene by $P$. aeruginosa/PE}

In the BDS process modified biocatalyst has been used either in the presence of potassium hexacyanoferrate(III) and without the electron accepting activity of this material to confirm this modification impact on the exhibition of adsorbed cells. Presence of potassium hexacyanoferrate(III), causes a greater extent and rate of biodegradation compared to the individual supported cells.

Optimum conditions for BDS activity of the biocatalyst have been investigated using different amount of biocatalyst in different initial concentration of thiophene as sulphur model compound of crude oil in different contact time, $\mathrm{pH}$ and temperature in all experiments were adjusted at the best metabolic condition $\left(\mathrm{pH}=7, T=37^{\circ} \mathrm{C}\right)$ for the bacterial strain. According to the BDS efficiency values, biodegradation of thiophene had a very small increment by increasing the amount of biocatalyst from 0.1 to $0.5 \mathrm{~g}$, because of increasing in active sites on biocatalyst surface by raising the biocatalyst amount. Also BDS efficiencies have been promoted by increasing contact time, but biocatalyst activity showed maximum efficiency at lower initial concentrations of thiophene. The BDS 
activities, expressed as the BDS efficiency of modified biocatalyst, each test has been repeated for three times (Table 1).

Table 1

Thiophene biodesulphurization by $P$. aeruginosa/PE

\begin{tabular}{|c|c|c|c|c|c|c|}
\hline $\begin{array}{c}\boldsymbol{C}_{\mathbf{0}} \\
{\left[\mathbf{m g} / \mathbf{d m}^{3}\right]}\end{array}$ & $\mathbf{p H}[-]$ & $\begin{array}{c}\boldsymbol{T} \\
{\left[{ }^{\circ} \mathbf{C}\right]}\end{array}$ & $\begin{array}{c}\text { Contact time } \\
{[\mathbf{m i n}]}\end{array}$ & $\begin{array}{c}\text { Biocatalyst } \\
\text { amount }[\mathbf{g}]\end{array}$ & $\begin{array}{c}\boldsymbol{C e} \\
{\left[\mathbf{m g} / \mathbf{d m}^{3}\right]}\end{array}$ & $\begin{array}{c}\text { BDS efficiency } \\
\mathbf{\pm R S D}[\mathbf{\%}]\end{array}$ \\
\hline 50 & 7 & 37 & 60 & 0.1 & 13.07 & $73.86 \pm 0.17$ \\
\hline 100 & 7 & 37 & 60 & 0.1 & 27.78 & $72.22 \pm 0.38$ \\
\hline 150 & 7 & 37 & 60 & 0.1 & 119.1 & $20.6 \pm 0.0$ \\
\hline 200 & 7 & 37 & 60 & 0.1 & 188.15 & $5.92 \pm 0.00$ \\
\hline 50 & 7 & 37 & 60 & 0.2 & 12.99 & $74.02 \pm 0.10$ \\
\hline 50 & 7 & 37 & 60 & 0.3 & 12.97 & $74.05 \pm 0.10$ \\
\hline 50 & 7 & 37 & 60 & 0.4 & 12.23 & $75.54 \pm 0.10$ \\
\hline 50 & 7 & 37 & 60 & 0.5 & 12.02 & $75.96 \pm 0.10$ \\
\hline 50 & 7 & 37 & 120 & 0.5 & 11.99 & $76.02 \pm 0.70$ \\
\hline 50 & 7 & 37 & 180 & 0.5 & 10.67 & $78.65 \pm 0.71$ \\
\hline 50 & 7 & 37 & 240 & 0.5 & 8.34 & $83.30 \pm 0.36$ \\
\hline
\end{tabular}

In the presence of $0.5 \mathrm{~g}$ biocatalyst, degradation efficiency for $50 \mathrm{mg} / \mathrm{dm}^{3}$ solution after $240 \mathrm{~min}$ of contact time was about $83.3 \%$. According to Table 2 in the presence of potassium hexacyanoferrate(III), BDS efficiency after $180 \mathrm{~min}$ of contact time was about $94.87 \%$.

Table 2

Thiophene biodesulphurization by $P$. aeruginosa/PE in the presence of potassium hexacyanoferrate(III)

\begin{tabular}{|c|c|c|c|c|c|c|}
\hline $\begin{array}{c}\boldsymbol{C}_{\mathbf{0}} \\
{\left[\mathbf{m g} / \mathbf{d m}^{\mathbf{3}}\right]}\end{array}$ & $\begin{array}{c}\mathbf{p H} \\
{[-]}\end{array}$ & $\begin{array}{c}\boldsymbol{T} \\
{\left[{ }^{\circ} \mathbf{C}\right]}\end{array}$ & $\begin{array}{c}\text { Contact time } \\
{[\mathbf{m i n}]}\end{array}$ & $\begin{array}{c}\text { Biocatalyst } \\
\text { amount }[\mathbf{g}]\end{array}$ & $\begin{array}{c}\boldsymbol{C e} \\
{\left[\mathbf{m g} / \mathbf{d m}^{\mathbf{3}}\right]}\end{array}$ & $\begin{array}{c}\text { BDS efficiency } \\
\mathbf{\pm R S D}[\boldsymbol{\%}]\end{array}$ \\
\hline 50 & 7 & 37 & 60 & 0.1 & 12.23 & $75.54 \pm 0.46$ \\
\hline 100 & 7 & 37 & 60 & 0.1 & 27.06 & $72.94 \pm 0.10$ \\
\hline 150 & 7 & 37 & 60 & 0.1 & 106.8 & $28.8 \pm 0.17$ \\
\hline 200 & 7 & 37 & 60 & 0.1 & 142.43 & $28.78 \pm 0.33$ \\
\hline 50 & 7 & 37 & 60 & 0.2 & 11.99 & $76.02 \pm 0.07$ \\
\hline 50 & 7 & 37 & 60 & 0.3 & 11.75 & $76.51 \pm 0.10$ \\
\hline 50 & 7 & 37 & 60 & 0.4 & 11.62 & $76.75 \pm 0.20$ \\
\hline 50 & 7 & 37 & 60 & 0.5 & 10.29 & $79.41 \pm 0.10$ \\
\hline 50 & 7 & 37 & 120 & 0.5 & 9.17 & $81.67 \pm 0.17$ \\
\hline 50 & 7 & 37 & 180 & 0.5 & 2.56 & $94.87 \pm 0.30$ \\
\hline
\end{tabular}

Table 2 also presents the trend in adsorption of thiophene onto biocatalyst for different contact times, it was observed that equilibrium was attained within $180 \mathrm{~min}$, but rapid initial adsorption was observed on biocatalyst at first 60 minutes and after that BDS efficiency increases slowly. This can be attributed to the quick adsorption of thiophene on to large surface area of biocatalyst that becomes occupied as the contact time is increased leading to slower rates as equilibrium approaches. With the passage of time, BDS process attains equilibrium and kinetics of the process can be studied.

\section{Kinetic studies for BDS of thiophene by $P$. aeruginosa/ PE}

Kinetic models were used to investigate obtained results in terms of order and rate constant for BDS process. Kinetic data were treated with the Lagergren pseudo-first-order (PFO) rate equation in linear form: 


$$
\log \left(q_{e}-q_{t}\right)=\log q_{e}-K_{1} / 2.303 t
$$

where $q_{e}$ is the amount of biosorbed thiophene on the biocatalyst at equilibrium condition $\left[\mathrm{mg} \cdot \mathrm{g}^{-1}\right], q_{t}$ values are the amounts of biosorbed thiophene on the biocatalyst at considered contact times $\left[\mathrm{mg} \cdot \mathrm{g}^{-1}\right] . K_{1}$ is the rate constant for Lagergren pseudo-first order kinetic [min ${ }^{-1}$ ] [43]. Values of $K_{1}$ and $q_{e}$ were calculated from slope and intercept of plot between $\log \left(q_{e}-q_{t}\right)$ and $t$.

$$
\left(t / q_{t}\right)=1 /\left(K_{2} q_{e}\right)^{2}+\left(1 / q_{e}\right) t
$$

where $q_{e}$ is the amount of biosorbed thiophene on the biocatalyst at equilibrium condition $\left[\mathrm{mg} \cdot \mathrm{g}^{-1}\right], q_{t}$ values are the amounts of biosorbed thiophene on the biocatalyst at considered contact times $\left[\mathrm{mg} \cdot \mathrm{g}^{-1}\right]$ and $K_{2}$ is the rate constant for pseudo-second order kinetic $\left[\mathrm{min}^{-1}\right][44]$.

Table 3 shows parameters for these two kinetic models. From the slope and intercept of linear plot of $t / q_{t}$ and $t$, values of $K_{2}$ and $q_{e}$ were calculated.

Table 3

Kinetic parameters for thiophene BDS by P.aeruginosa/ PE

\begin{tabular}{|c|c|c|c|c|c|c|}
\hline $\begin{array}{c}\boldsymbol{C}_{\mathbf{0}} \\
{\left[\mathbf{m g} / \mathbf{d m}^{3}\right]}\end{array}$ & $\begin{array}{c}\text { Contact } \\
{[\mathbf{m i n}]}\end{array}$ & $\begin{array}{c}\text { Biocatalyst } \\
\text { amount }[\mathbf{g}]\end{array}$ & $\begin{array}{c}\boldsymbol{C e} \\
{\left[\mathbf{m g} / \mathbf{d m}^{3}\right]}\end{array}$ & $\begin{array}{c}\boldsymbol{q}_{\boldsymbol{t}} \\
{\left[\mathbf{m g} \cdot \mathbf{g}^{-\mathbf{1}}\right]}\end{array}$ & $\boldsymbol{t} / \boldsymbol{q}_{\boldsymbol{t}}$ & $\log \left(\boldsymbol{q}_{\boldsymbol{e}}-\boldsymbol{q}_{\boldsymbol{t}}\right)$ \\
\hline 50 & 60 & 0.5 & 12.02 & 7.595 & 7.899 & -0.1324 \\
\hline 50 & 120 & 0.5 & 11.99 & 7.602 & 15.785 & -0.1363 \\
\hline 50 & 180 & 0.5 & 10.67 & 7.866 & 22.88 & -0.331 \\
\hline 50 & 240 & 0.5 & 8.34 & 8.333 & 28.8 & - \\
\hline
\end{tabular}

The data fitting for the thiophene adsorption on $P$. aeruginosa/PE for both models illustrates that pseudo-second order model fits well.
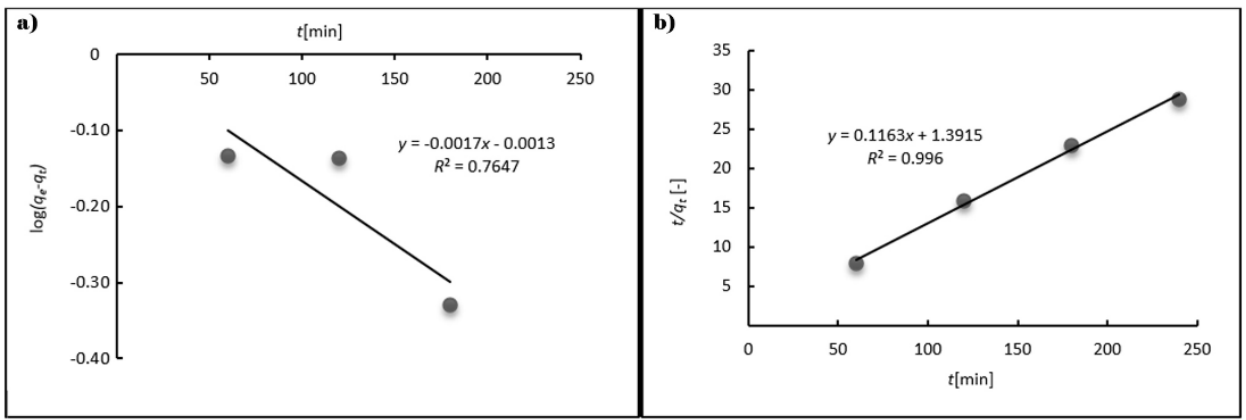

Fig. 3. a) Pseudo first order kinetic diagram $\left(K_{1}=0.0039 \mathrm{~min}^{-1}, q_{e 1}=0.997 \mathrm{mg} \cdot \mathrm{g}^{-1}\right)$, b) Pseudo-second order kinetic diagram $\left(K_{2}=0.0097 \mathrm{~min}^{-1}, q_{e 2}=8.5984 \mathrm{mg} \cdot \mathrm{g}^{-1}\right)$ for thiophene BDS by P. aeruginosa/ $\mathrm{PE}$

According to Figure 3, calculated $q_{e}$ value from pseudo-first order equation differed remarkably from the experimental one, this value suggested that thiophene BDS did not follow the PFO kinetic reaction.

Pseudo-second order kinetic describes adsorption of thiophene on the biocatalyst and biodegradation process, because of the higher rate constant $\left(K_{2}=0.0097 \mathrm{~min}^{-1}\right)$ and higher 
obtained correlation coefficient $\left(R^{2}=0.996\right)$ indicating a true linear relationship between the independent and dependent parameters for the equation, also the value of $q_{e}$ calculated from the pseudo-second-order equation was quite close to the experimental $q_{e}$ value.

Pseudo-second order kinetics demonstrate that chemisorption controls the adsorption of thiophene on biocatalyst and the rate of biocatalyst active sites occupation is associated to the squared numbers of unoccupied active sites on the surface of biocatalyst.

\section{Conclusions}

The bacterial cell immobilization by adsorption on polymeric supports is an effective methodology to modify BDS process. The biomodification of polyethylene by $P$. aeruginosa produces a new biocatalyst with an active metabolism that facilitate the interaction of bacterial strain with oil phase and improving the biocatalyst performance in comparison with non-modified supported cells. Also BDS activity in the presence of potassium hexacyanoferrate as an electron acceptor compound, accelerating the BDS process and improving the biocatalyst performance. The kinetic study predicted the chemisorption process, as it followed the pseudo-second-order rate equation. Thus, it can be concluded that P. aeruginosa/PE can be used as an efficient biocatalyst in BDS process of thiophenic compounds of crude oils.

\section{Acknowledgements}

This study was performed at Islamic Azad University, Kermanshah branch which is gratefully acknowledged.

\section{References}

[1] Leflaive P, Lemberton JL, Perot G, Mirgain C, Carriat JY, Colin JM. Appl Catal A: General. 2002;227:201-215. DOI: 10.1016/S0926-860X(01)00936-X.

[2] Song C. Catal Today. 2003;86:211-263. DOI: 10.1016/S0920-5861(03)00412-7.

[3] Brunet S, Mey D, Pérot G, Bouchy C, Diehl F. Appl Catal A: General. 2005;278:143-172. DOI: 10.1016/j.apcata.2004.10.012.

[4] Díaz E, Jiménez JI, Nogales J. Curr Opin Biotechnol. 2013;24:431-442. DOI: 10.1016/j.copbio.2012.10.010.

[5] Fujikawa T, Kimura H, Kiriyama K, Hagiwara K. Catal Today. 2006;111:188-193. DOI: 10.1016/j.cattod.2005.10.024.

[6] Ito E, Van Veen JR. Catal Today. 2006;116:446-460. DOI: 10.1016/j.cattod.2006.06.040.

[7] Gates BC, Katzer JR, Schuit GC. Chemistry of Catalytic Processes. New York: McGraw-Hill;1979.

[8] Kodama K, Umehara K, Shimizu K, Nakatani S, Minoda Y, Yamada K. Agric Biol Chem. 1973;37:45-50. DOI: $10.1080 / 00021369.1973 .10860640$.

[9] Setti L, Lanzarini G, Pifferi PG. Fuel Process Technol. 1997;52:145-153. DOI: 10.1016/S0378-3820(97)00023-4.

[10] Nuhu AA. Rev Environ Sci Bio/Technol. 2013;12:9-23. DOI: 10.1007/s11157-012-9267-x.

[11] Castorena G, Suárez C, Valdez I, Amador G, Fernández L, Le Borgne S. FEMS Microbiol Lett. 2002;215:157-161. DOI: 10.1111/j.1574-6968.2002.tb11385.x.

[12] Le Borgne S, Quintero R. Fuel Process Technol. 2003;81:155-169. DOI: 10.1016/S0378-3820(03)00007-9.

[13] Li W, Zhang Y, Wang MD, Shi Y. FEMS Microbiol Lett. 2005;247:45-50. DOI: 10.1016/j.femsle.2005.04.025.

[14] Kilbane JJ. Curr Opin Biotechnol. 2006;17:305-314. DOI: 10.1016/j.copbio.2006.04.005.

[15] Chen H, Zhang WJ, Chen JM, Cai YB, Li W. Bioresource Technol. 2008;99:3630-3634. DOI: 10.1016/j.biortech.2007.07.034.

[16] Li YG, Gao HS, Li WL, Xing JM, Liu HZ. Bioresource Technol. 2009;100:5092-5096. 10.1016/j.biortech.2009.05.064

[17] Juhasz AL, Naidu R. Int Biodeterior Biodegrad. 2000;45:57-88. DOI: 10.1016/S0964-8305(00)00052-4. 
[18] Xu R, Obbard JP. J Environ Qual. 2003;32:1234-1243. DOI: 10.2134/jeq2003.1234.

[19] Vieira PA, Vieira RB, De França FP, Cardoso VL. J Hazard Mater. 2007;140:52-59. DOI: 10.1016/j.jhazmat.2006.06.048.

[20] Oldfield C, Pogrebinsky O, Simmonds J, Olson ES, Kulpa CF. Microbiol. 1997;143:2961-2973. DOI: 10.1099/00221287-143-9-2961.

[21] Labana S, Pandey G, Jain RK. Lett Appl Microbiol. 2005;40:159-163. DOI: 10.1111/j.1472-765X.2004.01648.X.

[22] Li F, Zhang Z, Feng J, Cai X, Xu P. J Biotechnol. 2007;127:222-228. DOI: 10.1016/j.jbiotec.2006.07.002.

[23] Davoodi-Dehaghani F, Vosoughi M, Ziaee AA. Bioresour Technol. 2010;101:1102-1105. DOI: 10.1016/j.biortech.2009.08.058.

[24] Aggarwal S, Karimi IA, Kilbane II JJ, Lee DY. Mol BioSyst. 2012;8:2724-2732. DOI: $10.1039 / \mathrm{C} 2 \mathrm{MB} 25127 \mathrm{~B}$.

[25] Takada M, Nomura N, Okada H, Nakajima-Kambe T, Nakahara T, Uchiyama H. Biotechnol Lett. 2005;27:871-874. DOI: 10.1007/s10529-005-6721-7.

[26] Hou Y, Kong Y, Yang J, Zhang J, Shi D, Xin W. Fuel. 2005;84:1975-1979. DOI: 10.1016/j.fuel.2005.04.004.

[27] Shan G, Xing J, Zhang H, Liu H. Appl Environ Microbiol. 2005;71:4497-4502. DOI: 10.1128/AEM.71.8.4497-4502.2005.

[28] Feng J, Zeng Y, Ma C, Cai X, Zhang Q, Tong M, et al. Appl Environ Microbiol. 2006;72:7390-7393. DOI: 10.1128/AEM.01474-06.

[29] Shao P, Huang RY. J Membr Sci. 2007;287:162-179. DOI: 10.1016/j.memsci.2006.10.043.

[30] Hansen CM. Hansen Solubility Parameters: A User's Handbook. Boca Raton: CRC Press; 2007.

[31] Rychlewska K, Konieczny K, Bodzek M. Archives Environ Prot. 2015;41:3-11. DOI: 10.1515/aep-2015-0013.

[32] Chang JH, Chang YK, Ryu HW, Chang HN. FEMS Microbiol Lett. 2000;182:309-312. DOI: 10.1111/j.1574-6968.2000.tb08913.x.

[33] Zhang H, Shan G, Liu H, Xing J. Surf Coat Technol. 2007;201:6917-6921. DOI: 10.1016/j.surfcoat.2006.11.043.

[34] Luque-Almagro VM, Merchan F, Blasco R, Igeño MI, Martínez-Luque M, Moreno-Vivian C, et al. Microbiol. 2011;157:739-746. DOI: 10.1099/mic.0.045286-0.

[35] Catterall K, Zhao H, Pasco N, John R. Anal Chem. 2003;75:2584-2590. DOI: 10.1021/ac0206420.

[36] Caro A, Boltes K, Letón P, García-Calvo E. Biochem Eng J. 2007;35:191-197. DOI: 10.1016/j.bej.2007.01.013.

[37] Fatahi A, Sadeghi S. Lett Appl Microbiol. 2017;64:370-378. DOI: 10.1111/lam.12729.

[38] Dinamarca MA, Ibacache-Quiroga C, Baeza P, Galvez S, Villarroel M, Olivero P, et al. Bioresource Technol. 2010;101:2375-2378. DOI: 10.1016/j.biortech.2009.11.086.

[39] Yee N, Fein JB, Daughney CJ. Geochim Cosmochim Acta. 2000;64:609-617. DOI: 10.1016/S0016-7037(99)00342-7.

[40] Parikh SJ, Chorover J. Langmuir. 2006;22:8492-8500. DOI: 10.1021/la061359p.

[41] Jeyachandran YL, Narayandass SK, Mangalaraj D, Bao CY, Li W, Liao YM, et al. Surf Coat Technol. 2006;201:3462-3474. DOI: 10.1016/j.surfcoat.2006.07.236.

[42] Rong X, Huang Q, He X, Chen H, Cai P, Liang W. Colloids Surf B: Biointerfaces. 2008;64: 49-55. DOI: 10.1016/j.colsurfb.2008.01.008.

[43] Lagergren S. About the theory of so-called adsorption of soluble substances. K Svenska Vetenskapsakademiens Handl. 1898;24:1-39.

[44] Ho YS, McKay G. Process Biochem. 1999;34:451-465. DOI: 10.1016/S0032-9592(98)00112-5. 